\title{
Kamil Kotliński Konsekwencje brexitu dla finansów Unii Europejskiej
}

\section{Brexit and its consequences for the finances of the European Union}

The aim of the article is to identify the consequences of Brexit from the point of view of the EU finances. The first section focuses on the share of member states in the EU budget revenue. The author attempted to estimate the additional contribution of each member state. The second section briefly shows in which EU programmes the UK still takes part. The third section concentrates on the adjustment of the shares in the capital of the European Investment Bank and the European Central Bank to the reduced number of shareholders. The next part discusses the budgetary correction mechanisms as a historical remnant of the British rebate. In the last section the author describes the Brexit Adjustment Reserve, which supports regions and sectors most affected by the United Kingdom's withdrawal from the European Union.

\begin{tabular}{r|l}
\hline DOI & https://doi.org/10.31268/StudiaBAS.2021.30 \\
\hline Słowa kluczowe & $\begin{array}{l}\text { brexit, budżet Unii Europejskiej, wieloletnie ramy finansowe } \\
2021-2027\end{array}$ \\
\hline Keywords & $\begin{array}{l}\text { Brexit, budget of the European Union, 2021-2027 Multiannual } \\
\text { Financial Framework }\end{array}$ \\
\hline 0 autorze & $\begin{array}{l}\text { doktor nauk ekonomicznych, adiunkt, Katedra Teorii Ekonomii, } \\
\text { Uniwersytet Warmińsko-Mazurski w Olsztynie • } \\
\text { k.kotlinski@uwm.edu.pl • ORCID 0000-0002-5754-8363 }\end{array}$ \\
\hline
\end{tabular}

\section{Wstęp}

Wystąpienie Zjednoczonego Królestwa Wielkiej Brytanii i Irlandii Północnej z Unii Europejskiej (UE) zostało nazwane „brexitem”. Ten krótki neologizm szybko trafił do wielu języków jeszcze w okresie, gdy państwo to pozostawało członkiem Wspólnoty. Brexit należy postrzegać jako proces, a nie jednorazowe wydarzenie. Początkiem było referendum z 23 czerwca 2016 r., w którym obywatele tego państwa opowiedzieli się za wyjściem z UE. W konsekwencji brytyjski rząd, powołujący się na art. 50 Traktatu o Unii Europejskiej, 29 marca 2017 r. złożył oficjalną deklarację opuszczenia Unii. Rozmowy rozpoczęły się dopiero 19 czerwca 2017 r., a więc rok po referendum. Początkowo zakładano, że Zjednoczone Królestwo opuści UE w 2019 r., ale negocjacje trwały dłużej, kilkakrotnie odraczano bowiem datę formalnego wyjścia. Ostatecznie formalnie opuściło ono Unię Europejską 1 lutego 2020 r. Okres przejściowy, podczas którego pozostawało częścią jednolitego rynku i unii celnej, trwał do końca 2020 r. Jednocześnie prowadzono negocjacje w sprawie przyszłych stosunków. Po intensywnych rozmowach umowa o handlu i współpracy została podpisana 30 grudnia 2020 r., od 1 stycznia 2021 r. była tymczasowo stosowana i weszła w życie 1 maja 2021 r., po zatwierdzeniu przez Parlament Europejski 27 kwietnia 2021 r. ${ }^{1}$ Wyjście

1 Komisja Europejska, Umowa o handlu i współpracy między UE a Wielką Brytanią, https://ec.europa.eu/info/ relations-united-kingdom/eu-uk-trade-and-cooperation-agreement_pl [dostęp: 14 września 2021 r.]. 
z Unii Europejskiej państwa, które wytwarzało 16,2\% PKB całej Wspólnoty i jest zamieszkane przez $12,8 \%$ populacji UE, to wydarzenie bezprecedensowe i wieloaspektowe. Zjednoczone Królestwo było również dużym płatnikiem netto do budżetu UE, więc brexit pociąga za sobą poważne konsekwencje dla finansów Unii Europejskiej. Problem jest więc bardzo aktualny, mimo to dotychczas stosunkowo rzadko porusza się go w literaturze.

Głównym celem artykułu jest identyfikacja skutków wyjścia Wielkiej Brytanii z Unii Europejskiej z punktu widzenia finansów Wspólnoty, a także próba oceny wielkości wzrostu wpłat pozostałych państw członkowskich (w tym Polski) do wspólnego budżetu po wyjściu Wielkiej Brytanii. Postawiono hipotezę badawczą, zgodnie z którą w konsekwencji brexitu pozostałe państwa członkowskie ponoszą większe obciążenia finansowe na rzecz UE, przy czym największy wzrost odczuły Niemcy.

Do realizacji celu przyjęto metodę statyki porównawczej sytuacji finansowej UE przed brexitem i po nim. Skoncentrowano się na stronie dochodowej budżetu UE. Z wykorzystaniem metody analizy statycznej zbadano udział państw członkowskich w finansowaniu dochodów własnych ogółem UE. Przyjęto długi zakres czasowy, bo obejmujący lata 2004-2021. Przeprowadzono również analizę statyczną wybranych programów Unii Europejskiej, udziałów w Europejskim Banku Inwestycyjnym i Europejskim Banku Centralnym przed brexitem i po nim. Zastosowano także metodę analizy aktów prawnych UE i dokonano przeglądu literatury przedmiotu. Z badań wyłączono instrument odbudowy Next Generation EU.

\section{Problem sfinansowania ubytku dochodów spowodowanego brakiem Wielkiej Brytanii w UE}

W kampanii przedreferendalnej zwolennicy wyjścia Wielkiej Brytanii z UE podkreślali brak konieczności wpłat do budżetu unijnego jako jedną z podstawowych korzyści podjęcia tego kroku. Przemilczano natomiast to, że owo państwo również było beneficjentem środków z unijnego budżetu. Nie ulega jednak wątpliwości, że Zjednoczone Królestwo było jednym z największych płatników netto (największym płatnikiem netto są niezmiennie Niemcy). Zagregowane rozliczenia Wielkiej Brytanii z budżetem Unii Europejskiej w latach 2014-2020 zestawiono w tabeli 1. Wysokość brytyjskich płatności netto ulegała zmianom, niemniej wyjście tak dużego płatnika netto z UE skutkuje powstaniem poważnych niedoborów finansowych nazwanych „luką brexitową".

Zgodnie z umową o wystąpieniu z UE ${ }^{3}$ Wielka Brytania płaciła za swoje zobowiązania przyjęte w wieloletnich ramach finansowych 2014-2020. Po 2020 r. Zjednoczone Królestwo nie uczestniczy w budżecie Unii na dotychczasowych zasadach, co oznacza, że nie jest objęte systemem zasobów własnych Unii Europejskiej, a także nie podlega obowiązkowi wnoszenia wkładów umożliwiających realizację polityk unijnych finansowanych z funduszy UE, m.in. Europejskiego Funduszu Rozwoju Regionalnego, Europejskiego Funduszu Społecznego, Funduszu Spójności, Europej-

2 K. Stabryła-Chudzio, Perspektywy dla finansów Unii Europejskiej po rezygnacji z członkostwa Wielkiej Brytanii, „Studia Oeconomica Posnaniensia” 2018, t. 6, nr 2, s. 106-118, https://doi.org/10.18559/soep.2018.2.7.

3 Umowa o wystąpieniu Zjednoczonego Królestwa Wielkiej Brytanii i Irlandii Północnej z Unii Europejskiej i Europejskiej Wspólnoty Energii Atomowej (Dz.Urz. UE C 384 I z dnia 12 listopada 2019 r.). 
Tabela 1. Rozliczenia Wielkiej Brytanii z budżetem UE w latach 2014-2020 (w mld EUR)

\begin{tabular}{|l|r|r|r|r|r|r|r|}
\hline \multicolumn{1}{|c|}{ Lata } & $\mathbf{2 0 1 4}$ & $\mathbf{2 0 1 5}$ & $\mathbf{2 0 1 6}$ & $\mathbf{2 0 1 7}$ & $\mathbf{2 0 1 8}$ & $\mathbf{2 0 1 9}$ & $\mathbf{2 0 2 0}$ \\
\hline Środki z budżetu UE & 7,0 & 7,5 & 7,1 & 6,3 & 6,6 & 7,6 & 6,8 \\
\hline Wpłaty Wielkiej Brytanii (całkowite zasoby własne) & 14,1 & 21,4 & 16,6 & 13,8 & 16,4 & 17,1 & 19,7 \\
\hline Pozycja netto & $-7,1$ & $-13,9$ & $-9,5$ & $-7,5$ & $-9,8$ & $-9,5$ & $-12,9$ \\
\hline
\end{tabular}

Źródło: opracowanie własne na podstawie: Komisja Europejska, Roczny budżet UE, https://ec.europa.eu/info/ strategy/eu-budget/annual-eu-budget/all-annual-budgets_pl [dostęp: 14 września 2021 r.].

skiego Funduszu Rolnego na rzecz Rozwoju Obszarów Wiejskich oraz Europejskiego Funduszu Rolniczego Gwarancji ${ }^{4}$ W literaturze występują różne szacunki „luki brexitowej” po 2020 r. Różnice w ustaleniach wynikały przede wszystkim z przyjęcia jako podstawy do obliczeń różnych koncepcji rocznego budżetu UE, różnych lat i różnych metod szacowania (w szczególności włączenie lub wyłączenie rabatu brytyjskiego) $)^{5}$. Na przykład J. Haas i E. Rubio ${ }^{6}$ ustalili, że roczna kwota luki netto wynosi 10 mld EUR, E. Kawecka-Wyrzykowska ${ }^{7}$ - 16,5 mld EUR (jako średnia obliczona na podstawie danych z lat 2014-2015), a I. Begg ${ }^{8}$ - 17 mld EUR (średniorocznie za lata 2013-2015), tj. ok. 12\% dochodów budżetu UE. Można więc ostrożnie przyjąć kwotę od 10 do 17 mld EUR jako wysokość „luki brexitowej”. Wszystkie te szacunki zostały sporządzone na podstawie danych historycznych budżetu UE, nie uwzględniają inflacji ani nie zakładają zmian konstrukcji budżetu. W każdym jednak przypadku wniosek jest taki sam: po wyjściu Wielkiej Brytanii z Unii Europejskiej we wspólnym budżecie brakuje ogromnych ilości środków finansowych. Wielka Brytania była dużym płatnikiem netto do wspólnego budżetu, jej płatności netto sięgały ok. 5-7\% budżetu UE. Istniały poważne obawy, że dojdzie do zmniejszenia budżetu UE przez redukcję wydatków w ważnych dla Polski politykach: polityce spójności i wspólnej polityce rolnej9 ${ }^{9}$ Nowe wieloletnie ramy finansowe na lata 2021-2027 wynoszą jednak ok. 1211 mld EUR (zobowiązania, ceny bieżące $)^{10}$, co realnie przekłada się na utrzymanie poziomu wydatków z lat 2014-2020 ${ }^{11}$. Do tego

4 K. Marchewka-Bartkowiak, Postanowienia finansowe [w:] Brexit. Najważniejsze postanowienia umowy o wystapieniu Zjednoczonego Królestwa Wielkiej Brytanii i Irlandii Północnej z Unii Europejskiej i Europejskiej Wspólnoty Energii Atomowej, red. P. Russel, Wydawnictwo Sejmowe, Warszawa 2020, s. 38.

5 E. Kawecka-Wyrzykowska, Multiannual Financial Framework Post-2020: Brexit Implications, with a Focus on Poland, „Argumenta Oeconomica Cracoviensia” 2019, t. 21, nr 2, s. 62-63, https://doi.org/10.15678/ aoc.2019.2106.

6 J. Haas, E. Rubio, Brexit and the EU Budget: Threat or Opportunity?, "Jacques Delors Institute Policy Paper" 2017, $\mathrm{nr} 183$, s. 1.

7 E. Kawecka-Wyrzykowska, Implications of Brexit for Financing of the EU Budget, with Particular Stress on the Effects on Poland, „Unia Europejska.pl” 2018, nr 1, s. 5.

8 I. Begg, The EU Budget after 2020, „SIEPS European Policy Analysis” 2017, s. 2.

9 K. Kotliński, Brexit a polityka spójności , „Prace Naukowe Uniwersytetu Ekonomicznego we Wrocławiu” 2018, nr 536, s. 105-112.

10 Ostateczne przyjęcie (UE, Euratom) 2021/417 budżetu ogólnego Unii Europejskiej na rok budżetowy 2021 (Dz.Urz. UE L 93 z dnia 17 marca 2021 r.), s. 13.

11 S. Płóciennik, Wieloletnie ramy finansowe UE na lata 2021-2027: propozycje Komisji Europejskiej, „Biuletyn PISM” 2018, $\operatorname{nr} 72(1645)$. 
przewiduje się nowe źródła dochodów: 20-procentowy udział w dochodach z systemu handlu uprawnieniami do emisji $\mathrm{CO}_{2}$, 3-procentowy podatek od osób prawnych, a także obowiązujące już wpłaty państw członkowskich od niepoddanych recyklingowi odpadów opakowaniowych z tworzyw sztucznych (0,80 EUR za kilogram). Z jednej strony z nowymi źródłami dochodów wiązane są pewne nadzieje ${ }^{12}, z$ drugiej strony wiadomo, że pokryją nie więcej niż 5-7\% wydatków przewidzianych w perspektywie 2021-2027 ${ }^{13}$. Konieczne są więc zwiększone wpłaty pozostałych państw członkowskich. Osobnym, nieporuszanym tutaj zagadnieniem jest pozabudżetowy pakiet Next Generation EU, który ma być finansowany głównie z pożyczek wziętych na rynku kapitałowym.

Specyfika budżetu ogólnego UE polega na tym, że jest to budżet powiązany z dłuższą perspektywą finansową. Roczne budżety UE są uchwalane z uwzględnieniem wieloletnich ram finansowych (WRF), sporządzanych na okresy 7-letnie i pozwalających na podejmowanie wspólnych działań o horyzoncie czasowym dłuższym niż roczny. Wydatki zawarte w wieloletnich ramach finansowych są podzielone na grupy odzwierciedlające główne priorytety przyjęte przez państwa członkowskie, przy czym w odniesieniu do każdej z grup ustalany jest pułap zobowiązań finansowych na dany rok budżetowy. Wielkości zobowiązań oraz płatności są określane w euro (w cenach stałych i bieżących) oraz w relacji do dochodu narodowego brutto (DNB) Unii. Wielkość wydatków określonych w obowiązującej w danym czasie perspektywie jest corocznie aktualizowana z uwzględnieniem wzrostu cen oraz zmiany DNB. Wieloletnie ramy finansowe od budżetów rocznych odróżniają brak strony dochodowej oraz szczegółowe określenie wydatków na poziomie limitów w odniesieniu do głównych ich grup, co daje pewną swobodę przy kształtowaniu wysokości wydatków w ramach tych grup ${ }^{14}$.

Zgodnie z zasadą równowagi łączne wydatki Unii zapisane w budżecie muszą być równe łącznym dochodom. Punktem wyjścia przy określaniu wkładów państw członkowskich jest całkowita kwota zatwierdzonych wydatków (tabela 2). Niewielka część tej kwoty jest pokrywana z innych dochodów, takich jak podatki pobierane od wynagrodzeń pracowników Unii, odsetki od zaległych płatności, grzywny i wkłady państw spoza Unii na niektóre programy itp. Dochody budżetowe Unii nie pochodzą z wpływów uzyskiwanych z tytułu podatków, tak jak się to dzieje w przypadku budżetu państwowego ${ }^{15}$. Źródłem środków własnych są natomiast wpłaty państw członkowskich. Składają się na nie tradycyjne środki własne (tj. opłaty rolne oraz cła), środek własny obliczony na podstawie VAT, środek własny obliczony na podstawie dochodu narodowego brutto i inne wpływy, np. z odsetek ${ }^{16}$. Zasoby własne oparte na dochodzie narodowym brutto (DNB) to zasoby równoważące. Finansuje się z nich wszystkie te wydatki, które nie są pokrywane z innych źródeł dochodów, co oznacza, że dochody i wydatki zawsze pozostają w równowadze.

12 Ibidem, a także: A. Kłos, New Proposals for Financing the EU Budget after 2020, "Studia Europejskie” 2018, nr 4, s. 150-156.

13 A. Krenek, M. Sommer, M. Schratzenstaller, A WTO-compatible Border Tax Adjustment for the ETS to Finance the EU Budget, "WIFO Working Papers” 2021, nr 596.

14 Z. Szpringer, Budżet Unii Europejskiej a budżet państwa Polski, „Studia BAS” 2012, nr 3(31) [Finanse Unii Europejskiej, red. G. Gołębiowski], s. 133-160.

15 A. Wichowska, Makroekonomiczne funkcje budżetu Unii Europejskiej a wieloletnie ramy finansowe na lata 20142020, „Oeconomia Copernicana” 2013, nr 2, s. 27.

16 Z. Szpringer, op. cit., s. 144. 
Tabela 2. Budżet Unii Europejskiej w okresie 2021-2027 - perspektywa zobowiązań i perspektywa płatności (w mln EUR)

\begin{tabular}{|l|c|c|c|c|c|c|c|c|}
\hline & $\mathbf{2 0 2 1}$ & $\mathbf{2 0 2 2}$ & $\mathbf{2 0 2 3}$ & $\mathbf{2 0 2 4}$ & $\mathbf{2 0 2 5}$ & $\mathbf{2 0 2 6}$ & $\mathbf{2 0 2 7}$ & $\begin{array}{c}\text { WRF } \\
\mathbf{2 0 2 1 -} \\
\mathbf{2 0 2 7}\end{array}$ \\
\hline $\begin{array}{l}\text { Perspektywa } \\
\text { zobowiązań ogółem }\end{array}$ & 163483 & 165892 & 168761 & 172024 & 175632 & 179725 & 185337 & 1210894 \\
\hline $\begin{array}{l}\text { Perspektywa płatności } \\
\text { ogółem }\end{array}$ & 166140 & 167585 & 165542 & 168853 & 172230 & 175674 & 179187 & 1195211 \\
\hline
\end{tabular}

Źródło: Ostateczne przyjęcie (UE, Euratom) 2021/417 budżetu ogólnego Unii Europejskiej na rok budżetowy 2021 (Dz.Urz. UE L 93 z dnia 17 marca 2021 r.), s. 13.

Dochody budżetowe w 2021 r. wynoszą ogółem 166 mld EUR. Jednolita stawka poboru stosowana w odniesieniu do zasobów opartych na VAT wynosi 0,3\%, natomiast stawka poboru w odniesieniu do zasobów opartych na DNB - 0,8659\%. W budżecie na 2021 r. tradycyjne zasoby własne zapewniają 10,60\% środków finansowych, zasoby oparte na VAT - 10,82\%, a zasoby oparte na DNB - 73,04\%. Pozostałe dochody na ten rok budżetowy szacuje się na 9,2 mld EUR. Również w latach 2007-2020 całkowite zasoby własne pokrywały ok. 90\% dochodów budżetu UE. Kwota zasobów własnych potrzebna do sfinansowania budżetu na 2021 r. odpowiada 1,12\% łącznego DNB. Ogółem zasoby własne w 2021 r. to kwota 156,9 mld EUR ${ }^{17}$.

Unia Europejska nie ma własnych służb celnych ani skarbowych, funkcjonariusze państw członkowskich są jednocześnie funkcjonariuszami Unii. W praktyce to państwa członkowskie przekazują środki do budżetu Wspólnoty, stąd bardzo łatwo ocenić dochody budżetu UE w podziale na państwa. W tabeli 3 zestawiono udział państw członkowskich w finansowaniu zasobów własnych ogółem w latach 2014-2021, na które składają się: tradycyjne zasoby własne, zasoby oparte na VAT i zasoby oparte na wielkości DNB państw członkowskich. Warto zwrócić uwagę, że wysokość tych udziałów się zmieniała. W przypadku Polski obserwujemy systematyczny wzrost - od 2,97\% w 2014 r. do 3,54\% w 2020 r. Ten wzrost obciążeń finansowych jest pośrednim skutkiem sukcesu naszego państwa, a zatem szybszego wzrostu gospodarczego niż średnio w UE oraz szybszego wzrostu konsumpcji, czyli bazy podatku VAT. Ponieważ jest to głównie udział obliczany na podstawie DNB, im większy udział Polski w DNB Unii Europejskiej, tym większy udział w finansowaniu budżetu UE. Podobną tendencję można zaobserwować w przypadku Bułgarii, Czech, Estonii, Węgier, Rumunii, a więc państw doganiających liderów. Procesy te można dostrzec również we wcześniejszym okresie 2004-2013 (tabela 4). Odwrotną tendencję zaobserwowano w przypadku takich państw, jak Grecja, Hiszpania czy Włochy. W 2021 r. (względem 2020 r.) udział Polski w zasobach własnych ogółem wzrósł z 3,54\% do $3,71 \%$. Oznacza to, że suma wpłat jest większa o 147,4 mln EUR, największy dodatkowy ciężar ponoszą jednak Niemcy. Ich udział jako płatnika zwiększył się z 19,95\% w 2020 r. do 25,36\% w 2021 r., co oznacza wpłaty wyższe aż o 7 mld 842 mln EUR.

17 Ostateczne przyjęcie..., s. 66. 
Tabela 3. Udział państw członkowskich UE w finansowaniu zasobów własnych UE w latach 2014-2021 (w \%)

\begin{tabular}{|c|c|c|c|c|c|c|c|c|}
\hline Państwo & 2014 & 2015 & 2016 & 2017 & 2018 & 2019 & 2020 & 2021 \\
\hline Austria & 2,16 & 1,99 & 2,39 & 2,30 & 2,45 & 2,33 & 2,35 & 2,70 \\
\hline Belgia & 3,94 & 3,98 & 4,59 & 4,41 & 4,16 & 4,21 & 4,12 & 4,40 \\
\hline Bułgaria & 0,35 & 0,35 & 0,35 & 0,39 & 0,41 & 0,40 & 0,42 & 0,45 \\
\hline Chorwacja & 0,32 & 0,29 & 0,34 & 0,35 & 0,34 & 0,34 & 0,34 & 0,36 \\
\hline Cypr & 0,12 & 0,17 & 0,14 & 0,14 & 0,14 & 0,14 & 0,15 & 0,15 \\
\hline Czechy & 1,13 & 1,12 & 1,31 & 1,34 & 1,40 & 1,38 & 1,42 & 1,46 \\
\hline Dania & 1,89 & 1,84 & 1,81 & 1,97 & 2,02 & 1,90 & 1,97 & 2,22 \\
\hline Estonia & 0,15 & 0,15 & 0,16 & 0,16 & 0,17 & 0,19 & 0,19 & 0,21 \\
\hline Finlandia & 1,43 & 1,35 & 1,58 & 1,50 & 1,51 & 1,50 & 1,54 & 1,63 \\
\hline Francja & 15,77 & 15,00 & 16,78 & 15,51 & 15,61 & 15,74 & 15,83 & 17,07 \\
\hline Grecja & 1,47 & 0,98 & 1,31 & 1,22 & 1,17 & 1,21 & 1,16 & 1,30 \\
\hline Hiszpania & 8,36 & 7,35 & 8,72 & 8,33 & 8,32 & 8,16 & 7,73 & 8,69 \\
\hline Holandia & 6,30 & 5,79 & 3,72 & 5,07 & 5,16 & 5,56 & 5,64 & 6,73 \\
\hline Irlandia & 1,24 & 1,34 & 1,61 & 1,79 & 1,83 & 1,59 & 1,63 & 1,82 \\
\hline Litwa & 0,29 & 0,28 & 0,31 & 0,31 & 0,31 & 0,32 & 0,34 & 0,37 \\
\hline Luksemburg & 0,19 & 0,27 & 0,25 & 0,29 & 0,26 & 0,27 & 0,25 & 0,31 \\
\hline Łotwa & 0,20 & 0,17 & 0,20 & 0,19 & 0,19 & 0,20 & 0,20 & 0,22 \\
\hline Malta & 0,06 & 0,08 & 0,07 & 0,08 & 0,08 & 0,09 & 0,08 & 0,09 \\
\hline Niemcy & 21,92 & 20,48 & 19,24 & 20,52 & 20,56 & 20,66 & 19,95 & 25,36 \\
\hline Polska & 2,97 & 3,08 & 3,25 & 3,22 & 3,31 & 3,48 & 3,54 & 3,71 \\
\hline Portugalia & 1,31 & 1,20 & 1,36 & 1,33 & 1,32 & 1,32 & 1,36 & 1,48 \\
\hline Rumunia & 1,10 & 1,05 & 1,19 & 1,21 & 1,29 & 1,31 & 1,40 & 1,50 \\
\hline Słowacja & 0,54 & 0,51 & 0,59 & 0,60 & 0,60 & 0,58 & 0,60 & 0,65 \\
\hline Słowenia & 0,29 & 0,29 & 0,32 & 0,31 & 0,32 & 0,33 & 0,33 & 0,37 \\
\hline Szwecja & 3,23 & 2,93 & 2,41 & 2,73 & 2,67 & 2,46 & 2,86 & 3,30 \\
\hline Węgry & 0,75 & 0,78 & 0,84 & 0,84 & 0,89 & 0,89 & 0,92 & 0,97 \\
\hline Wielka Brytania & 10,58 & 15,59 & 12,58 & 11,92 & 11,52 & 11,84 & 12,31 & 0,32 \\
\hline Włochy & 11,95 & 11,59 & 12,57 & 11,99 & 11,96 & 11,60 & 11,36 & 12,17 \\
\hline Ogółem & 100,00 & 100,00 & 100,00 & 100,00 & 100,00 & 100,00 & 100,00 & 100,00 \\
\hline
\end{tabular}

Źródło: opracowanie własne na podstawie danych Komisji Europejskiej: Roczny budżet UE, https://ec.europa. eu/info/strategy/eu-budget/annual-eu-budget/all-annual-budgets_pl [dostęp: 14 września 2021 r.]; Finansowanie planu odbudowy UE, 2020, https://ec.europa.eu/info/sites/default/files/about_the_european_commission/ eu_budget/2020.2139_pl_04.1.pdf [dostęp: 14 września 2021 r.]. 
Tabela 4. Udział państw członkowskich UE w finansowaniu zasobów własnych UE w latach 2004-2013 (w \%)

\begin{tabular}{|c|c|c|c|c|c|c|c|c|c|c|}
\hline Państwo & 2004 & 2005 & 2006 & 2007 & 2008 & 2009 & 2010 & 2011 & 2012 & 2013 \\
\hline Austria & 2,15 & 2,13 & 2,16 & 2,02 & 1,97 & 2,13 & 2,21 & 2,24 & 2,27 & 2,28 \\
\hline Belgia & 4,05 & 3,99 & 4,06 & 3,97 & 4,17 & 4,28 & 4,02 & 4,11 & 4,05 & 3,79 \\
\hline Bułgaria & 0,00 & 0,00 & 0,00 & 0,26 & 0,33 & 0,36 & 0,30 & 0,33 & 0,32 & 0,34 \\
\hline Chorwacja & 0 & 0 & 0 & 0 & 0 & 0 & 0 & 0 & 0 & 0,17 \\
\hline Cypr & 0,10 & 0,15 & 0,15 & 0,15 & 0,16 & 0,18 & 0,15 & 0,15 & 0,14 & 0,13 \\
\hline Czechy & 0,59 & 0,98 & 1,01 & 1,06 & 1,26 & 1,26 & 1,26 & 1,40 & 1,23 & 1,16 \\
\hline Dania & 2,04 & 1,97 & 2,14 & 2,02 & 2,07 & 2,29 & 2,00 & 2,04 & 2,08 & 2,07 \\
\hline Estonia & 0,06 & 0,10 & 0,13 & 0,16 & 0,15 & 0,15 & 0,12 & 0,13 & 0,14 & 0,15 \\
\hline Finlandia & 1,52 & 1,45 & 1,52 & 1,48 & 1,54 & 1,67 & 1,43 & 1,63 & 1,55 & 1,55 \\
\hline Francja & 16,85 & 16,72 & 16,25 & 15,45 & 16,21 & 18,45 & 16,44 & 16,35 & 16,45 & 16,67 \\
\hline Grecja & 1,83 & 1,79 & 1,79 & 2,75 & 2,09 & 2,23 & 1,94 & 1,59 & 1,39 & 1,36 \\
\hline Hiszpania & 8,82 & 9,40 & 9,57 & 8,94 & 8,96 & 10,26 & 8,48 & 9,21 & 8,30 & 8,14 \\
\hline Holandia & 5,54 & 5,90 & 5,99 & 5,73 & 6,00 & 3,06 & 4,71 & 4,89 & 4,70 & 4,69 \\
\hline Irlandia & 1,32 & 1,43 & 1,45 & 1,44 & 1,42 & 1,41 & 1,17 & 1,12 & 1,11 & 1,24 \\
\hline Litwa & 0,13 & 0,21 & 0,23 & 0,25 & 0,30 & 0,30 & 0,23 & 0,25 & 0,26 & 0,29 \\
\hline Luksemburg & 0,24 & 0,23 & 0,21 & 0,27 & 0,23 & 0,26 & 0,22 & 0,24 & 0,21 & 0,23 \\
\hline Łotwa & 0,07 & 0,13 & 0,15 & 0,18 & 0,19 & 0,20 & 0,15 & 0,15 & 0,18 & 0,19 \\
\hline Malta & 0,03 & 0,05 & 0,05 & 0,05 & 0,05 & 0,06 & 0,05 & 0,06 & 0,05 & 0,06 \\
\hline Niemcy & 21,28 & 19,97 & 20,03 & 19,74 & 19,98 & 18,83 & 19,96 & 19,27 & 20,25 & 21,02 \\
\hline Polska & 1,38 & 2,31 & 2,39 & 2,55 & 3,12 & 2,88 & 3,07 & 2,98 & 3,02 & 3,02 \\
\hline Portugalia & 1,40 & 1,51 & 1,35 & 1,33 & 1,32 & 1,50 & 1,55 & 1,45 & 1,36 & 1,28 \\
\hline Rumunia & 0,00 & 0,00 & 0,00 & 0,99 & 1,10 & 1,23 & 0,96 & 1,02 & 1,13 & 1,05 \\
\hline Słowacja & 0,23 & 0,36 & 0,39 & 0,47 & 0,54 & 0,65 & 0,54 & 0,58 & 0,57 & 0,57 \\
\hline Słowenia & 0,18 & 0,27 & 0,27 & 0,33 & 0,37 & 0,39 & 0,32 & 0,33 & 0,31 & 0,30 \\
\hline Szwecja & 2,82 & 2,63 & 2,64 & 2,65 & 2,90 & 1,70 & 2,72 & 2,78 & 2,90 & 3,01 \\
\hline Węgry & 0,57 & 0,83 & 0,76 & 0,79 & 0,85 & 0,83 & 0,80 & 0,78 & 0,72 & 0,72 \\
\hline Wielka Brytania & 12,29 & 12,06 & 12,10 & 12,21 & 9,10 & 9,28 & 12,31 & 11,52 & 12,50 & 12,21 \\
\hline Włochy & 14,50 & 13,44 & 13,20 & 12,75 & 13,62 & 14,16 & 12,88 & 13,40 & 12,78 & 12,29 \\
\hline Ogółem & 100,00 & 100,00 & 100,00 & 100,00 & 100,00 & 100,00 & 100,00 & 100,00 & 100,00 & 100,00 \\
\hline
\end{tabular}

Źródło: opracowanie własne na podstawie danych Komisji Europejskiej: Roczny budżet... oraz Finansowanie planu..

Budżet na 2021 r. zawiera również wpłaty Wielkiej Brytanii. Zapłaci ona 498 mln EUR tytułem należności celnych netto, tzn. po odliczeniu zryczałtowanych kosztów poboru. Ogółem należności celne netto wszystkich państw członkowskich opiewają na 17 mld 605,7 mln EUR, a zatem w 2021 r. Wielka Brytania sfinansuje 2,83\% wpływów z tytułu należności celnych netto, zaliczanych do tradycyjnych zasobów własnych ${ }^{18}$.

18 Ibidem, s. 46. 
Tabela 5. Średni udział państw członkowskich UE w finansowaniu zasobów własnych UE w latach 2007-2013 i 2014-2020 oraz w 2021 r. (w \%)

\begin{tabular}{|c|c|c|c|c|c|}
\hline Państwo & $\begin{array}{c}\text { Średnia } \\
2007-2013\end{array}$ & $\begin{array}{c}\text { Średnia } \\
2014-2020\end{array}$ & 2021 & $\begin{array}{c}\text { Różnica } \\
\text { między } \\
2021 \text { a średnią } \\
2014-2020 \\
\text { (w p.p.) }\end{array}$ & $\begin{array}{c}\text { Wzrost } \\
\text { składki } \\
\text { (w mln EUR) }\end{array}$ \\
\hline Austria & 2,16 & 2,28 & 2,70 & $+0,42$ & 658,8 \\
\hline Belgia & 4,06 & 4,20 & 4,40 & $+0,2$ & 313,7 \\
\hline Bułgaria & 0,32 & 0,38 & 0,45 & $+0,07$ & 109,8 \\
\hline Chorwacja & 0,17 & 0,33 & 0,36 & $+0,03$ & 47,1 \\
\hline Cypr & 0,15 & 0,14 & 0,15 & $+0,01$ & 15,7 \\
\hline Czechy & 1,23 & 1,30 & 1,46 & $+0,16$ & 251,0 \\
\hline Dania & 2,08 & 1,91 & 2,22 & $+0,31$ & 486,3 \\
\hline Estonia & 0,14 & 0,17 & 0,21 & $+0,04$ & 62,7 \\
\hline Finlandia & 1,55 & 1,49 & 1,63 & $+0,14$ & 219,6 \\
\hline Francja & 16,57 & 15,75 & 17,07 & $+1,32$ & 2070,6 \\
\hline Grecja & 1,91 & 1,22 & 1,30 & $+0,08$ & 125,5 \\
\hline Hiszpania & 8,90 & 8,14 & 8,69 & $+0,55$ & 862,8 \\
\hline Holandia & 4,83 & 5,32 & 6,73 & $+1,41$ & 2211,8 \\
\hline Irlandia & 1,27 & 1,58 & 1,82 & $+0,24$ & 376,5 \\
\hline Litwa & 0,27 & 0,31 & 0,37 & $+0,06$ & 94,1 \\
\hline Luksemburg & 0,24 & 0,25 & 0,31 & $+0,06$ & 94,1 \\
\hline Łotwa & 0,18 & 0,19 & 0,22 & $+0,03$ & 47,1 \\
\hline Malta & 0,05 & 0,08 & 0,09 & $+0,01$ & 15,7 \\
\hline Niemcy & 19,86 & 20,48 & 25,36 & $+4,88$ & 7655,1 \\
\hline Polska & 2,95 & 3,26 & 3,71 & $+0,45$ & 705,9 \\
\hline Portugalia & 1,40 & 1,31 & 1,48 & $+0,17$ & 266,7 \\
\hline Rumunia & 1,07 & 1,22 & 1,50 & $+0,28$ & 439,2 \\
\hline Słowacja & 0,56 & 0,57 & 0,65 & $+0,08$ & 125,5 \\
\hline Słowenia & 0,34 & 0,31 & 0,37 & $+0,06$ & 94,1 \\
\hline Szwecja & 2,67 & 2,76 & 3,30 & $+0,54$ & 847,1 \\
\hline Węgry & 0,78 & 0,84 & 0,97 & $+0,13$ & 203,9 \\
\hline Wielka Brytania & 11,30 & 12,33 & 0,32 & $-12,01$ & $-18839,8$ \\
\hline Włochy & 13,13 & 11,86 & 12,17 & $+0,31$ & 486,3 \\
\hline Ogółem & 100,14 & 100,00 & 100,00 & - & - \\
\hline
\end{tabular}

Źródło: opracowanie własne na podstawie danych Komisji Europejskiej: Roczny budżet UE, https://ec.europa.eu/ info/strategy/eu-budget/annual-eu-budget/all-annual-budgets_pl [dostęp: 9 czerwca 2021 r.]. 
Znacznie większą kwotą, bo aż 7,2 mld EUR, został zasilony budżet w 2021 r. przez Wielką Brytanię z tytułu 6 „Dochody, wkłady i zwroty związane z politykami Unii” w rozdziale 6.6 „Inne wkłady i zwroty"199. Zgodnie z umową o wystąpieniu z UE Zjednoczone Królestwo jest jeszcze płatnikiem do unijnego budżetu. Kwota ta jest jednak znacznie mniejsza niż w ubiegłych latach. Z tego powodu pozostałe państwa członkowskie muszą wpłacać więcej niż dotychczas.

W tabeli 5 zestawiono średni udział w finansowaniu zasobów własnych ogółem w latach 2007-2013, w okresie 2014-2020 oraz w 2021 r. Wyjście Wielkiej Brytanii z UE spowodowało, że udział pozostałych 27 państw członkowskich wzrósł. Wzrost udziału (w p.p.) w finansowaniu zasobów własnych ogółem przedstawiono w przedostatniej kolumnie tabeli 5. Ostatnia kolumna tabeli 5 zawiera wzrost obciążeń danego państwa wobec budżetu UE w 2021 r. względem średniej w latach 2014-2020 w mln EUR. Wielkości te oszacowano przez pomnożenie wzrostu udziału w zasobach własnych ogółem danego państwa (kolumna 5) przez wartość zasobów własnych ogółem budżetu UE na 2021 r., czyli 156,9 mld EUR. Można tak obliczone kwoty zinterpretować jako przybliżony wzrost wartości składki danego państwa spowodowany brexitem. 0 tyle niższe byłyby składki państw członkowskich, gdyby Wielka Brytania wciąż była pełnoprawnym członkiem UE w 2021 r.

Największy koszt ponoszą Niemcy - 7 mld 655,1 mln EUR. Na drugim miejscu jest Holandia z kwotą dodatkowej płatności szacowaną na 2 mld 211 mln EUR. Francja płaci o 2 mld 71 mln EUR więcej. Tak obliczony koszt brexitu w wysokości prawie 706 mln EUR daje Polsce szóste miejsce w rankingu płatników zwiększonej składki, po Hiszpanii i Szwecji, ale przed Austrią, Włochami i Danią.

\section{Zobowiązania brytyjskie po wyjściu z Unii Europejskiej}

Zwolennicy brexitu spodziewali się, że wraz z wyjściem z Unii Europejskiej wygasną również zobowiązania wobec unijnego budżetu. Już w lutym 2017 r. Komisja Europejska szacowała jednak kwotę zobowiązań Wielkiej Brytanii wobec UE na 60 mld EUR ${ }^{20}$. Ta kwota obejmuje potencjalne zobowiązania w trzech głównych obszarach, do których należą:

- Zatwierdzone podczas członkostwa Wielkiej Brytanii w UE, prawnie wiążące zobowiązania budżetowe, których płatność przypada po wyjściu Wielkiej Brytanii z UE.

- Emerytury obiecane urzędnikom UE.

- Zobowiązania warunkowe, takie jak pożyczki ratunkowe dla Irlandii - płatności mogą być konieczne w pewnych okolicznościach ${ }^{21}$.

Istotną cechą konstrukcyjną budżetu Unii Europejskiej jest posługiwanie się w planowaniu budżetowym dwoma odrębnymi ujęciami strony wydatkowej, mianowicie rozróżnia się perspektywę płatności oraz perspektywę zobowiązań22 . Perspektywa zobowiązań to przypadające

19 Ibidem, s. 132.

20 K. Kotliński, Skutki brexitu dla budżetu Unii Europejskiej, „Prace Naukowe Uniwersytetu Ekonomicznego we Wrocławiu" 2017, nr 498, s. 163.

21 A. Barker, The $€ 60$ Billion Brexit Bill: How to Disentangle Britain from the EU Budget, Centre for European Reform, 2017, s. 1-14.

22 A. Wernik, Finanse publiczne, Polskie Wydawnictwo Ekonomiczne, Warszawa 2014, s. 211-212. 
na dany rok finansowy wydatki z tytułu działań zaplanowanych do realizacji w okresie przekraczającym dany rok budżetowy. Dotyczą one głównie grantów finansowanych w ramach działań strukturalnych mających charakter wieloletni. Po stronie Unii Europejskiej podnoszono, że nie byłoby właściwe, by podatnicy 27 państw płacili za zobowiązania podjęte przez 28 członków UE²3. Te wspólnie podjęte w przeszłości zobowiązania zostały uznane przez Wielką Brytanię za obowiązki prawne również po opuszczeniu UE. Nie są to płatności natychmiastowe, lecz rozłożone na kilka lat, a część z nich (np. udzielone gwarancje) ma charakter potencjalny. Zgodnie z umową wystąpienia z UE Wielka Brytania będzie partycypować w przypadającej na nią części zobowiązań. W budżecie na 2021 r. w rozdziale 6.6 „Inne wkłady i zwroty” wkład Zjednoczonego Królestwa związany z art. 148 umowy o wystąpieniu opiewa na kwotę 7,2 mld EUR ${ }^{24}$. Są to zobowiązania podjęte jeszcze w okresie członkostwa.

Brytyjska opinia publiczna potraktowała roszczenia Brukseli jako koszty ugody, opłatę za wyjście i dostęp do wspólnego rynku. Taka ocena jest niewłaściwa. Wielka Brytania będzie po prostu płacić wcześniej podjęte zobowiązania, a ich ostateczna wysokość jest niewiadomą i będzie zależała od przyszłych wydarzeń, takich jak kursy walut i budżety UE. Brytyjski Urząd ds. Odpowiedzialności Fiskalnej (Office for Budget Responsibility) szacuje, że koszt netto Wielkiej Brytanii może wynieść 34 mld funtów ${ }^{25}$. Trzeba przy tym zaznaczyć, że szacunki te zakładają okres 2020-2064, a więc długoterminowy. Na lata 2021-2028 przypada natomiast niecałe 19 mld funtów.

Wielka Brytania po zakończeniu okresu przejściowego (od 1 stycznia 2021 r.) nadal uczestniczy w niektórych programach UE. Umowa o handlu i współpracy między Wielką Brytanią a UE stanowi, że Wielka Brytania nadal będzie brała udział w następujących programach UE:

- Horyzont Europa - unijny program badań i innowacji,

- program badawczo-szkoleniowy Euratom,

- międzynarodowy eksperymentalny reaktor termojądrowy (ITER) - obiekt do testowania syntezy jądrowej, budowany obecnie na południu Francji,

- Copernicus - satelitarny system UE do monitorowania Ziemi².

Wielka Brytania będzie wnosić wkład finansowy, aby wziąć udział w tych programach. Przyszłe wpłaty nie są częścią rozliczenia finansowego, które dotyczy pozostających do spłaty zobowiązań finansowych wynikających z członkostwa Wielkiej Brytanii w UE, ale są kosztem udziału w programach UE. Na wkład finansowy, który będzie obliczony w przyszłości, składają się:

- składka oparta na zamożności Wielkiej Brytanii (proporcjonalnie do jej PKB) w porównaniu z zamożnością UE,

- opłata za uczestnictwo pokrywająca koszty administracyjne organizacji systemu programów unijnych,

23 European Commission, Speech by Michel Barnier at the Press Conference Following the Third Round of Article 50 Negotiations with the United Kingdom, https://ec.europa.eu/commission/presscorner/detail/en/ SPEECH_17_3043 [dostęp: 14 września 2021 r.].

24 Ostateczne przyjęcie..., s. 132.

25 M. Keep, Brexit: The Financial Settlement - In Detail, „House of Commons Library Briefing Paper” 2021, nr 8039, s. 4.

26 Ibidem, s. 5. 
- dodatkowo w przypadku Horyzontu Europa standardowy mechanizm dostosowawczy zapewniający równowagę między składkami Wielkiej Brytanii a jej korzyściami²7.

Umowa obejmuje również obszary finansowe, które są formalnie poza budżetem UE. Należą do nich: rozliczenia finansowe związane z Europejskim Bankiem Inwestycyjnym, Europejskim Bankiem Centralnym, Europejskim Funduszem Inwestycyjnym, pomoc dla uchodźców w Turcji i fundusze pomocowe European Union Emergency Trust Fund for stability and addressing root causes of irregular migration and displaced persons in Africa (EUTF for Africa).

Europejski Fundusz Rozwoju (EFR) jest głównym instrumentem UE służącym do udzielania pomocy rozwojowej państwom spoza UE. Od 2021 r. fundusz ten został włączony do budżetu unijnego. Wielka Brytania wciąż będzie partycypować w kosztach tego przedsięwzięcia. Zjednoczone Królestwo pozostaje uczestnikiem EFR do czasu zamknięcia trwającej obecnie edycji zgodnie z podpisaną umową wewnętrzną. Jednocześnie przyjmuje się, że Wielka Brytania dokona wpłat za poprzednie niezakończone jeszcze edycje EFR (od 4. do 10.). Oznacza to, że rząd brytyjski będzie nadal zobowiązany do wpłacania odpowiednich kwot do EFR, ale tym samym beneficjenci tego funduszu ze Zjednoczonego Królestwa nadal będą kwalifikować się do udziału w projektach realizowanych w ramach dotychczasowych edycji rozpoczętych przed datą formalnego wystąpienia z UE ${ }^{28}$. Brytyjskie ministerstwo skarbu szacuje, że środki wpłacone przez Wielką Brytanię na rzecz EFR wyniosą 2,9 mld funtów. Obowiązek wygaśnie w 2026 r. Państwo to ma ponadto udział w Funduszu Inwestycyjnym EFR w wysokości ok. 0,4 mld funtów, ale środki te zostaną zwrócone Wielkiej Brytanii po zakończeniu inwestycji. Zjednoczone Królestwo wywiąże się również ze swoich zobowiązań podjętych w ramach Instrumentu Pomocy dla Uchodźców w Turcji oraz europejskich funduszy pomocowych EUTF for Africa. Składki Wielkiej Brytanii z tego tytułu wynoszą 146 mln funtów. Instrument Pomocy dla Uchodźców w Turcji został utworzony jako część szerszego programu mającego rozwiązać kryzys migracyjny. Instrument koncentruje się na pomocy humanitarnej, edukacji, zarządzaniu migracją, zdrowiu, infrastrukturze i wsparciu społeczno-gospodarczym. Fundusze EUTF to narzędzia rozwojowe, które łączą zasoby różnych darczyńców w celu umożliwienia reakcji UE w sytuacjach nadzwyczajnych lub pokryzysowych ${ }^{29}$.

Wbrew oczekiwaniom zwolenników brexitu pomimo wyjścia z Unii Europejskiej Wielka Brytania wciąż ma swój udział w finansowaniu wielu programów UE oraz unijnego budżetu. Pozostaje sprawą otwartą, w jakim zakresie będzie uczestniczyć w przyszłych edycjach europejskich funduszy pomocowych skierowanych do krajów trzecich.

\section{Wycofanie udziałów brytyjskich w Europejskim Banku Inwestycyjnym i Europejskim Banku Centralnym}

Państwa członkowskie UE są również członkami Europejskiego Banku Inwestycyjnego (EBI). Wystąpienie Wielkiej Brytanii z UE automatycznie kończy jej członkostwo w EBI. Udział tego

27 Ibidem.

28 K. Marchewka-Bartkowiak, op. cit., s. 45-46.

29 M. Keep, op. cit., s. 11-12. 
państwa w EBI wynosił 16,11\% subskrybowanego kapitału ${ }^{30}$. Wpłacone środki w wysokości 3,5 mld EUR zostaną Wielkiej Brytanii zwrócone w rocznych ratach do 2031 r. Płatności rozpoczęły się 15 października 2020 r., a udziały Brytyjczyków zostały proporcjonalnie rozdzielone pomiędzy pozostałe państwa członkowskie, kapitał zaś uzupełniono z rezerwy. W przypadku Polski i Rumunii udział w Europejskim Banku Inwestycyjnym został asymetrycznie zwiększony. Polska podwyższyła swój kapitał w EBI o 5 mld 386 mln EUR, z czego kapitał wpłacony to zaledwie 8,919255272\% ${ }^{31}$, czyli 480 mln EUR. Reszta to gwarancje płatne w razie potrzeby. Dzięki tej decyzji udział Polski w kapitale EBI wzrósł z 2\% do 4,57\%32. Pod względem wielkości udziałowców Polska przesunęła się zatem z 10. miejsca na 7. Zwiększenie udziałów Polski przełoży się na większe wpływy i siłę głosu w radzie dyrektorów EBI, która podejmuje decyzje w sprawie kierunków polityki banku. Należy jednak pamiętać, że największe udziały (a więc i siłę głosu) mają Niemcy, Francja i Włochy (po 19\%).

Brexit nie wpłynie na działalność finansową ani na model biznesowy EBI. Wielka Brytania nie wycofała się ze zobowiązań podjętych przed brexitem i zgadza się zapewnić 39 mld EUR kapitału wymaganego lub na żądanie ${ }^{33}$. Są to gwarancje, a więc kapitał zostanie udzielony w razie potrzeby. Gwarancje te będą się zmniejszać wraz ze spadkiem kredytów EBI z nimi związanych.

Wszystkie państwa członkowskie UE, również te pozostające poza strefą euro, uczestniczą w Europejskim Systemie Banków Centralnych (ESBC). Zgodnie z umową wyjścia z UE Wielka Brytania otrzyma zwrot swojego udziału w Europejskim Banku Centralnym (EBC) w wysokości 58 mln EUR. Dotychczasowy udział Zjednoczonego Królestwa w kapitale EBC kształtował się na poziomie $14,3 \%$, co dawało Wielkiej Brytanii drugą pozycję wśród wszystkich państw członkowskich Unii Europejskiej ${ }^{34}$.

Po wystąpieniu Bank of England z Europejskiego Systemu Banków Centralnych subskrybowany kapitał Europejskiego Banku Centralnego się nie zmieni i nadal będzie wynosić 10,8 mld EUR. W związku z tym subskrybowany kapitał EBC zostanie na nowo rozdzielony między pozostałe krajowe banki centralne na podstawie zaktualizowanego klucza subskrypcji. Wagi procentowe poszczególnych banków zostały przeliczone według udziału państw członkowskich w łącznej liczbie ludności i PKB całej Unii Europejskiej po wystąpieniu z niej Wielkiej Brytanii. Klucz subskrypcji kapitału EBC przed wyjściem Wielkiej Brytanii i po brexicie został przedstawiony w tabeli 6 . Najbardziej zwiększyły swój udział największe państwa strefy euro, takie jak Niemcy, Francja i Włochy. Udziały banków centralnych państw ze strefy euro wzrosły z 69,6\% do 81,3\%, a udział krajowych banków centralnych spoza strefy euro spadł z 30,4\% do 18,7\% - Wielka Brytania była największym państwem spoza strefy euro w Europejskim Systemie Banków Centralnych. Wraz z jej wyjściem grupa ta może w przyszłości tracić na znaczeniu i być marginalizowana.

30 European Investment Bank, EIB President Regrets Brexit and Welcomes EU 27 United Support for EIB Group, http://www.eif.europa.eu/what_we_do/news/eib-president-regrets-brexit-welcomes-eu27-united-support-for-eib-group.htm?lang=-en [dostęp: 14 września 2021 r.].

31 European Investment Bank, Statute and other Treaty provisions, Version dated 1 March 2020, s. 8-9.

32 Ibidem.

33 M. Keep, op. cit., s. 11.

34 K. Marchewka-Bartkowiak, op. cit., s. 43. 
Tabela 6. Klucz subskrypcji kapitału Europejskiego Banku Centralnego przed brexitem i po nim

\begin{tabular}{|c|c|c|}
\hline Krajowy bank centralny & $\begin{array}{c}\text { Klucz subskrypcji } \\
\text { kapitału EBC przed } \\
\text { brexitem, od } \\
1.01 .2019 \text { r. (w \%) }\end{array}$ & $\begin{array}{l}\text { Klucz kapitałowy } \\
\text { po brexicie (w \%) }\end{array}$ \\
\hline Nationale Bank van België (Belgia) & 2,5280 & 2,9630 \\
\hline Deutsche Bundesbank (Niemcy) & 18,3670 & 21,4394 \\
\hline Eesti Pank (Estonia) & 0,1968 & 0,2291 \\
\hline Banc Ceannais na hÉireann (Irlandia) & 1,1754 & 1,3772 \\
\hline Bank of Greece (Grecja) & 1,7292 & 2,0117 \\
\hline Banco de España (Hiszpania) & 8,3391 & 9,6981 \\
\hline Banque de France (Francja) & 14,2061 & 16,6108 \\
\hline Banca d'Italia (Włochy) & 11,8023 & 13,8165 \\
\hline Central Bank of Cyprus (Cypr) & 0,1503 & 0,1750 \\
\hline Latvijas Banka (Łotwa) & 0,2731 & 0,3169 \\
\hline Lietuvos bankas (Litwa) & 0,4059 & 0,4707 \\
\hline Banque centrale du Luxembourg (Luksemburg) & 0,2270 & 0,2679 \\
\hline Bank Centrali ta' Malta ( Malta) & 0,0732 & 0,0853 \\
\hline De Nederlandsche Bank (Holandia) & 4,0677 & 4,7662 \\
\hline Oesterreichische Nationalbank (Austria) & 2,0325 & 2,3804 \\
\hline Banco de Portugal (Portugalia) & 1,6367 & 1,9035 \\
\hline Banka Slovenije (Słowenia) & 0,3361 & 0,3916 \\
\hline Národná banka Slovenska (Słowacja) & 0,8004 & 0,9314 \\
\hline Suomen Pankki - Finlands Bank (Finlandia) & 1,2708 & 1,4939 \\
\hline Razem krajowe banki centralne ze strefy euro & 69,6176 & 81,3286 \\
\hline Българска народна банка (Bułgaria) & 0,8511 & 0,9832 \\
\hline Česká národní banka (Czechy) & 1,6172 & 1,8794 \\
\hline Danmarks Nationalbank (Dania) & 1,4986 & 1,7591 \\
\hline Hrvatska narodna banka (Chorwacja) & 0,5673 & 0,6595 \\
\hline Magyar Nemzeti Bank (Węgry) & 1,3348 & 1,5488 \\
\hline Narodowy Bank Polski (Polska) & 5,2068 & 6,0335 \\
\hline Banca Naţională a României (Rumunia) & 2,4470 & 2,8289 \\
\hline Sveriges Riksbank (Szewcja) & 2,5222 & 2,9790 \\
\hline Bank of England (Wielka Brytania) & 14,3374 & - \\
\hline Razem krajowe banki centralne spoza strefy euro & 30,3824 & 18,6714 \\
\hline
\end{tabular}

Źródło: Europejski Bank Centralny, Subskrybowany kapitał EBC nie zmieni się po wystapieniu Bank of England z Europejskiego Systemu Banków Centralnych, Komunikat prasowy, 30 stycznia 2020 r.

W wyniku brexitu udział Polski w kapitale EBC wzrósł z 5,2\% do 6\%. Kwotowo oznacza to wzrost kapitału subskrybowanego z 563,6 mln EUR do 653,1 mln EUR. Opłacony kapitał rośnie jednak z 21,1 mln EUR do 24,5 mln EUR. Krajowe banki centralne ze strefy euro opłacają 100\% 
subskrybowanego przez siebie kapitału EBC, a krajowe banki centralne spoza strefy euro $3,75 \%$. Ponieważ udziały krajowych banków centralnych ze strefy euro zwiększą się i zostaną opłacone w całości, łączny opłacony kapitał EBC wzrośnie z 7,659 mld EUR w 2020 r. do 8,88 mld EUR w 2022 r. Banki centralne państw członkowskich pokrywają wycofany przez Bank of England kapitał. Podwyższone udziały kapitałowe banków ze strefy euro mają zostać opłacone w dwóch rocznych ratach w latach 2021 i 2022. Te zmiany zostaną uwzględnione w bilansach krajowych banków centralnych i potraktowane jako inwestycje.

\section{Historyczna pozostałość rabatu brytyjskiego - mechanizm korekcyjny}

Już na początku lat 80. XX w. władze Wielkiej Brytanii podnosiły, że stosunek wpłat do transferów jest dla tego państwa nieakceptowalny. W 1984 r. na posiedzeniu Rady Europejskiej w Fontainebleau przyznano Zjednoczonemu Królestwu "rabat brytyjski”. Postanowiono także, że każde państwo członkowskie z nadmiernym obciążeniem budżetowym w stosunku do jego względnej zamożności może skorzystać z korekty w odpowiednim czasie. W ustaleniach nie określono, czym są "nadmierne obciążenia budżetowe” czy „względna zamożność" - pozostawiono to do swobodnej interpretacji. Na tę zasadę powoływały się więc często także inne państwa, które chciały obniżyć swoje wpłaty do wspólnego budżetu ${ }^{35}$, bo uważały, że płacą zbyt dużo, nawet jeśli obliczenia opierały się na obiektywnych kryteriach gospodarczych. Podjęto zatem działania, aby skorygować wkłady finansowe Danii, Niemiec, Holandii, Austrii i Szwecji. Podobne korekty dokonywane będą dla tych państw także w latach 2021-2027.

Instytucje Unii Europejskiej wielokrotnie podkreślały, że konieczne jest zreformowanie systemu zasobów własnych, a tym samym - mechanizmów korekcyjnych w budżecie UE, których niejasne sposoby obliczania komplikują system finansowy Unii. W 2014 r. (a więc jeszcze przed referendum w sprawie brexitu) powołano Grupę Wysokiego Szczebla ds. Zasobów Własnych, aby zbadać, w jaki sposób system finansowania budżetu UE można uczynić bardziej sprawiedliwym, prostszym, bardziej przejrzystym i demokratycznie rozliczalnym. Zgodnie ze sprawozdaniem końcowym i z zaleceniami Grupy Wysokiego Szczebla co do przyszłego finansowania $U^{36}$ Komisja zaproponowała stopniowe wygaszanie wszelkich korekt po stronie dochodów w ramach sprawiedliwego i zrównoważonego budżetu. Wprowadzenie takich zmian spowodowałoby jednak znaczny wzrost wpłat państw członkowskich korzystających obecnie z obniżek ${ }^{37}$, więc na nadzwyczajnym posiedzeniu Rady Europejskiej w lipcu 2020 r. państwa członkowskie postanowiły utrzymać rabaty. W latach 2021-2027 korekty ryczałtowe obniżą roczny wkład oparty na DNB wnoszony przez Danię, Niemcy, Holandię, Austrię i Szwecję. Korekty ryczałtowe dla wspomnianych państw wynoszą obecnie (w cenach z 2020 r.):

35 M. Proczek, P. Pajda, Mechanizmy korekcyjne w zasobach własnych budżetu Unii Europejskiej ze szczególnym uwzględnieniem rabatu brytyjskiego, „Studia Europejskie” 2017, nr 1, s. 125-126.

36 European Commission, Future Financing of the EU. Final Report and Recommendations of the High Level Group on Own Resource, 2016, https://ec.europa.eu/info/sites/default/files/about_the_european_commission/ eu_budget/future-financing-hlgor-final-report_2016_en.pdf [dostęp: 14 września 2021 r.].

37 E. Kawecka-Wyrzykowska, Multiannual Financial..., s. 65. 
- Dania - 377 mln EUR,

- Niemcy - 3671 mln EUR,

- Holandia - 1921 mln EUR,

- Austria - 565 mln EUR,

- Szwecja - 1069 mln EUR ${ }^{38}$.

Rabaty są finansowane przez wszystkie pozostałe państwa członkowskie zgodnie z ich DNB. Przy założeniu, że udział Polski w DNB całej UE-27 będzie wynosił ok. 6,5\% ${ }^{39}$, można w przybliżeniu oszacować koszt Polski z tytułu korekt ryczałtowych na ok. 494 mln EUR. W interesie naszego państwa jest więc likwidacja wszelkich mechanizmów korekcyjnych, ponieważ obecnie wszystkie tego typu narzędzia są stosowane wobec najbogatszych państw, co prowadzi do kuriozalnej sytuacji, w której ogromna część rabatu brytyjskiego jest finansowana przez najbiedniejszych członków UE ${ }^{40}$.

System finansowania budżetu UE jest uważany za skomplikowany, niesprawiedliwy i nieprzejrzysty ze względu na rabaty oraz mechanizmy korekcyjne. Mechanizmy korekcyjne, które na początku miały być wyjątkiem stosowanym tylko w przypadku Wielkiej Brytanii, stały się istotnym elementem tego systemu ${ }^{41}$. Wraz z wyjściem Wielkiej Brytanii z Unii Europejskiej zniknął rabat brytyjski, tym samym dalsze istnienie „rabatu od rabatu brytyjskiego" wydaje się bezzasadne. Niestety, mimo że Wielka Brytania nie jest już członkiem UE ani nie ma rabatu brytyjskiego, mechanizmy korekcyjne redukujące udział najbogatszych państw członkowskich w finansowaniu unijnego budżetu wciąż są stosowane.

\section{Rezerwa budżetowa na dostosowania wynikające z brexitu}

W związku z wyjściem Wielkiej Brytanii z UE wiele przedsiębiorstw i całych sektorów gospodarki staje przed problemami spowodowanymi utrudnieniami w dostępie do rynku brytyjskiego lub w inny sposób odczuwa skutki brexitu. Sytuacja ta może spowodować utratę miejsc pracy. Jednym z sektorów, który najbardziej ucierpi z powodu brexitu, jest branża rybołówstwa ze względu na ograniczenie działalności połowowej w brytyjskiej strefie ekonomicznej. Również administracje publiczne państw członkowskich musiały przystosować się do nowej sytuacji - np. w dziedzinie ceł i podatków pośrednich poczyniły znaczne inwestycje w infrastrukturę, nowe obiekty i zasoby ludzkie. Podobnie było w przypadku kontroli sanitarnych i fitosanitarnych państwa członkowskie musiały utworzyć nowe punkty kontroli granicznej lub rozszerzyć istniejące w punktach wejścia dla towarów przywożonych ze Zjednoczonego Królestwa do UE. Musiano także dostosować przepisy w zakresie wydawania certyfikatów i zezwoleń na produkty, wymogów dotyczących przedsiębiorstw, etykietowania i znakowania, a także w kwestii przewidywania

38 Komisja Europejska, Rabaty: mechanizmy korekty, https://ec.europa.eu/info/strategy/eu-budget/long-term-eu-budget/2021-2027/revenue/rebates_pl [dostęp: 15 września 2021 r.].

39 W momencie pisania tego tekstu (wrzesień 2021 r.) Eurostat podaje jedynie szacunkowe dane.

40 J. Hofmokl, Polska wobec Rabatu Brytyjskiego i reformy budżetu UE, „Analizy i Opinie Instytutu Spraw Publicznych" 2004, nr 20, s. 6.

41 M. Proczek, P. Pajda, op. cit., s. 130. 
konsekwencji, jakie wyjście Wielkiej Brytanii z UE będzie miało dla obywateli i przedsiębiorstw, oraz aktualizowania środków podnoszenia świadomości tych zmian.

W ciągu 47 lat członkostwa Zjednoczonego Królestwa w UE nawiązano bliskie stosunki gospodarcze i można założyć, że uszczerbek, jaki poniosą poszczególne sektory gospodarki, regiony i państwa członkowskie, nie będzie taki sam dla wszystkich. Będą mniej lub bardziej poszkodowani przez brexit. W związku z tym ustanowiono nową specjalną rezerwę na dostosowanie się do brexitu, łagodzącą jego wpływ na sytuację gospodarczą, spójność społeczną i terytorialną ${ }^{42}$. Celem rezerwy jest wsparcie państw członkowskich, regionów i sektorów, w szczególności tych najbardziej dotkniętych negatywnymi skutkami wyjścia Zjednoczonego Królestwa z UE. Zapewni ona wkłady finansowe na pokrycie całości lub części dodatkowych wydatków publicznych poniesionych przez państwa członkowskie, zwłaszcza te najbardziej uzależnione od stosunków handlowych i gospodarczych z Wielką Brytanią. Rezerwa uzupełnia inne istniejące narzędzia dostępne w ramach Next Generation EU i wieloletnich ram finansowych na lata 2021-2027.

Artykuł 10 Rozporządzenia Rady (UE, Euratom) 2020/2093³ przewiduje, że wysokość całkowitej kwoty rezerwy to 5 mld EUR w cenach z 2018 r. Maksymalne środki na wdrożenie rezerwy wynoszą 5,37 mld EUR w cenach bieżących i mają być traktowane jako specjalny instrument będący poza pułapami budżetu UE określonymi w wieloletnich ramach finansowych. Kwota zaliczki 4 mld EUR (w cenach z 2018 r.) zostanie przydzielona i wypłacona w trzech ratach: 1,6 mld EUR w 2021 r., 1,2 mld EUR w 2022 r. i 1,2 mld EUR w 2022 r. Pozostała kwota 1 mld EUR (w cenach z 2018 r.) zostanie przydzielona i wydatkowana w 2025 r. ${ }^{44}$ Chociaż jest prawdopodobne, że większość negatywnych skutków wyjścia Wielkiej Brytanii z Unii Europejskiej nastąpi w pierwszym roku po brexicie, konsekwencje dla niektórych regionów, sektorów lub państw członkowskich mogą być odczuwalne także w kolejnych latach.

Wkład finansowy z rezerwy wspiera wyłącznie wydatki publiczne bezpośrednio powiązane z dostosowaniem się do sytuacji po brexicie państw członkowskich i może obejmować w szczególności:

- pomoc przedsiębiorstwom i społecznościom lokalnym poszkodowanym przez brexit,

- wsparcie najbardziej dotkniętych sektorów gospodarki,

- wsparcie przedsiębiorstw i społeczności lokalnych zależnych od działalności połowowej na wodach Zjednoczonego Królestwa,

- wspieranie zatrudnienia, w tym przez programy pracy skróconej, przekwalifikowanie i szkolenie w dotkniętych brexitem sektorach,

- funkcjonowanie kontroli granicznych, celnych, sanitarnych i fitosanitarnych, bezpieczeństwa i kontroli rybołówstwa, a także pobieranie podatków pośrednich, do którego konieczne jest zatrudnienie dodatkowego personelu i rozbudowa infrastruktury,

42 Wniosek Rozporządzenie Parlamentu Europejskiego i Rady ustanawiające pobrexitową rezerwę dostosowawczą (COM(2020) 854 final) z dnia 25 grudnia 2020 r.

43 Rozporządzenie Rady (EU, Euratom) 2020/2093 z dnia 17 grudnia 2020 r. określające wieloletnie ramy finansowe na lata 2021-2027 (Dz.Urz. UE L 433 I z dnia 22 grudnia 2020 r.), s. 11.

44 Regulation on Brexit Adjustment Reserve (BAR) - Analysis of the final compromise text with a view to agreement (COM(2020) 854 final) z dnia 25 czerwca 2021 r. 
- usprawnienie systemów certyfikacji i uproszczenie wydawania zezwoleń na produkty, pomoc przedsiębiorstwom w spełnieniu nowych wymogów, ułatwienie etykietowania i znakowania, na przykład w zakresie norm bezpieczeństwa, zdrowia i ochrony środowiska, a także pomoc we wzajemnym uznawaniu norm, wymogów i certyfikatów,

- informowanie o zmianie praw obywateli oraz przedsiębiorstw i obowiązków wynikających z brexitu ${ }^{45}$.

Do skorzystania z pomocy finansowej kwalifikują się wszystkie podmioty, które podejmują działania bezpośrednio związane z łagodzeniem negatywnych skutków brexitu. Podstawę rozdziału środków pomiędzy państwa członkowskie tworzą trzy główne czynniki: wartości ryb poławianych w wyłącznej strefie ekonomicznej Wielkiej Brytanii, wielkość handlu danego państwa z Wielką Brytanią oraz sytuacja ludności regionów nadmorskich graniczących z Wielką Brytanią. Ogółem $600 \mathrm{mln}$ EUR zostanie rozdysponowane na podstawie czynnika związanego z rybołówstwem, 4,15 mld EUR - w oparciu o wielkość handlu, a $250 \mathrm{mln}$ EUR - na podstawie czynnika związanego z sytuacją w przygranicznych regionach nadmorskich ${ }^{46}$. Zgodnie z tymi kryteriami Polska nie będzie największym beneficjentem tego funduszu, ale może on być potencjalnym źródłem wsparcia również dla podmiotów z Polski.

Rezerwa budżetowa na dostosowanie się do sytuacji wynikającej z brexitu to uzupełnienie innych programów i instrumentów finansowania Unii i zapewnienie synergii między nimi. Wieloletnie ramy finansowe na lata 2021-2027 i programy towarzyszące, w tym środki na poprawę gospodarczej spójności i pomoc terytoriom Europy (REACT-UE) w ramach funduszy strukturalnych i spójności, fundusze polityki spójności po 2020 r., Fundusz na rzecz Sprawiedliwej Transformacji, Instrument na rzecz Odbudowy i Zwiększania Odporności oraz InvestEU skupiają się bardziej na radzeniu sobie ze skutkami kryzysu wywołanego przez COVID-19, a wsparcie z tych funduszy ma sprawić, że gospodarki państw członkowskich będą bardziej odporne, zrównoważone i lepiej przygotowane na przyszłe wyzwania. Rezerwa związana z brexitem została ustanowiona wyłącznie w celu zmniejszenia bezpośrednich skutków wystąpienia Zjednoczonego Królestwa z Unii Europejskiej.

\section{Podsumowanie}

Wielka Brytania opuściła Unię Europejską 31 stycznia 2020 r. Okres przejściowy trwał do końca 2020 r., a zatem do końca 2020 r. Wielka Brytania płaciła swoje zobowiązania finansowe wobec Unii Europejskiej i korzystała na przyjętych wcześniej zasadach z unijnego budżetu. Budżet UE na 2021 r. jest pierwszym nieuwzględniającym Wielkiej Brytanii.

Zjednoczone Królestwo było jednym z największych płatników netto do budżetu UE, co oznacza, że więcej do budżetu UE wpłacało, niż z niego otrzymywało. Brytyjskie płatności netto sięgały 7\% budżetu UE, co po wyjściu Wielkiej Brytanii przekłada się na „lukę brexitową” szacowaną - w zależności od przyjętych metod obliczeń i założeń - na 10-17 mld EUR. Wieloletnie

45 Wniosek Rozporządzenie Parlamentu Europejskiego...

46 Regulation on Brexit... 
ramy finansowe na lata 2021-2027 pozostały w podobnej wysokości do poprzednich, więc musiała wzrosnąć kontrybucja nałożona na pozostałe państwa członkowskie. Nie ma podstaw do odrzucenia hipotezy, że w konsekwencji brexitu obciążenia finansowe pozostałych państw członkowskich wzrosły, zwłaszcza w przypadku Niemiec. Udział Niemiec w finansowaniu zasobów własnych ogółem zwiększył się z 19,95\% do 25,36\%, podczas gdy udział Polski wzrósł w stosunkowo niewielkim stopniu - z 3,54\% do 3,71\%. Spowodowany brexitem wzrost składki niemieckiej został oszacowany na 7,8 mld EUR w 2021 r.; Polska pod tym względem zajmuje szóste miejsce, ze wzrostem składki w wyniku brexitu w wysokości 706 mln EUR. Należy się przygotować na wyższe niż w poprzedniej perspektywie finansowej wpłaty Polski do budżetu UE.

Wielka Brytania nie jest już członkiem UE, ale wciąż bierze udział w finansowaniu niektórych unijnych programów. Jej łączny udział w dochodach budżetu UE wynosi w 2021 r. 7,7 mld EUR. Oprócz tego uczestniczy finansowo w pozabudżetowych funduszach pomocowych adresowanych do państw trzecich: Europejskim Funduszu Inwestycyjnym i Instrumencie Pomocy dla Uchodźców w Turcji.

Wraz z wyjściem Zjednoczonego Królestwa z Unii Europejskiej zakończyło się członkostwo tego państwa w Europejskim Banku Inwestycyjnym oraz Europejskim Banku Centralnym. Polska wykorzystała okazję do zwiększenia swoich udziałów, a tym samym swojej siły wpływów w EBI. Wychodzący z UE Bank of England wycofał także swój kapitał z Europejskiego Banku Centralnego, który został pokryty przez zwiększenie udziałów banków centralnych pozostałych państw członkowskich. Wraz z wyjściem Wielkiej Brytanii udział krajów spoza strefy euro w EBC został zmniejszony, nie ma to jednak wpływu na funkcjonowanie ani EBC, ani Europejskiego Systemu Banków Centralnych.

Mimo że Wielka Brytania nie jest już członkiem UE ani nie ma rabatu brytyjskiego, w perspektywie 2021-2027 utrzymano mechanizm korekcyjny obniżający wpłaty Danii, Niemiec, Holandii, Austrii i Szwecji. Brexit był okazją, aby uprościć system finansowy Unii Europejskiej i zrezygnować ze wszystkich mechanizmów korekcyjnych, które są stosowane wobec najbogatszych państw, a finansowane przez najbiedniejszych członków UE. To byłoby korzystne dla Polski. Niestety tak się nie stało.

Pozostająca poza wieloletnimi ramami finansowymi rezerwa budżetowa na dostosowania wynikające z brexitu wynosi 5 mld EUR. Środki te są zarezerwowane na pomoc dla przedsiębiorstw, sektorów, regionów i państw najbardziej dotkniętych gospodarczymi i społecznymi skutkami brexitu. Według przyjętych kryteriów Polska nie jest głównym adresatem tego funduszu, ale może on być potencjalnym źródłem wsparcia również dla podmiotów z Polski. Jest to instrument uzupełniający, mający zmniejszyć bezpośrednie negatywne skutki wyjścia Wielkiej Brytanii z UE.

\section{Bibliografia}

Barker A., The $€ 60$ Billion Brexit Bill: How to Disentangle Britain from the EU Budget, Centre for European Reform, 2017.

Begg I., The EU Budget after 2020, „SIEPS European Policy Analysis” 2017, s. 1-11. 
Europejski Bank Centralny, Subskrybowany kapitał EBC nie zmieni się po wystapieniu Bank of England z Europejskiego Systemu Banków Centralnych, Komunikat prasowy, 30 stycznia 2020.

Haas J., Rubio E., Brexit and the EU Budget: Threat or Opportunity?, "Jacques Delors Institute Policy Paper" 2017, nr 183, s. 1-18.

Hofmokl J., Polska wobec Rabatu Brytyjskiego i reformy budżetu UE, „Analizy i Opinie Instytutu Spraw Publicznych” 2004, nr 20.

Kawecka-Wyrzykowska E., Implications of Brexit for Financing of the EU Budget, with Particular Stress on the Effects on Poland, „Unia Europejska.pl” 2018, nr 1(248).

Kawecka-Wyrzykowska E., Multiannual Financial Framework Post-2020: Brexit Implications, with a Focus on Poland, „Argumenta Oeconomica Cracoviensia” 2019, nr 2(21), https://doi.org/10.15678/aoc.2019.2106.

Keep M., Brexit: The Financial Settlement - In Detail, "House of Commons Library Briefing Paper” 2021, nr 8039.

Kłos A., New Proposals for Financing the EU Budget after 2020, "Studia Europejskie” 2018, nr 4.

Kotliński K., Brexit a polityka spójności, „Prace Naukowe Uniwersytetu Ekonomicznego we Wrocławiu” 2018, nr 536, http://dx.doi.org/10.15611/pn.2018.536.09.

Kotliński K., Skutki brexitu dla budżetu Unii Europejskiej, „Prace Naukowe Uniwersytetu Ekonomicznego we Wrocławiu" 2017, nr 498, https://doi.org/10.15611/pn.2017.498.15.

Krenek A., Sommer M., Schratzenstaller M., A WTO-compatible Border Tax Adjustment for the ETS to Finance the EU Budget, „WIFO Working Papers” 2021, nr 596.

Marchewka-Bartkowiak K., Postanowienia finansowe [w:] Brexit. Najważniejsze postanowienia umowy o wystapieniu Zjednoczonego Królestwa Wielkiej Brytanii i Irlandii Północnej z Unii Europejskiej i Europejskiej Wspólnoty Energii Atomowej, red. P. Russel, Wydawnictwo Sejmowe, Warszawa 2020.

Płóciennik S., Wieloletnie ramy finansowe UE na lata 2021-2027: propozycje Komisji Europejskiej, "Biuletyn PISM” 2018, $\mathrm{nr}$ 72(1645).

Proczek M., Pajda P., Mechanizmy korekcyjne w zasobach własnych budżetu Unii Europejskiej ze szczególnym uwzględnieniem rabatu brytyjskiego, „Studia Europejskie” 2017, nr 1.

Stabryła-Chudzio K., Perspektywy dla finansów Unii Europejskiej po rezygnacji z członkostwa Wielkiej Brytanii, „Studia Oeconomica Posnaniensia" 2018, t. 6, nr 2.

Szpringer Z., Budżet Unii Europejskiej a budżet państwa Polski, „Studia BAS” 2012, nr 3(31) [Finanse Unii Europejskiej, red. G. Gołębiowski].

Wernik A., Finanse publiczne, Polskie Wydawnictwo Ekonomiczne, Warszawa 2014.

Wichowska A., Makroekonomiczne funkcje budżetu Unii Europejskiej a wieloletnie ramy finansowe na lata 2014-2020, „Oeconomia Copernicana” 2013, t. 4, nr 2, https://doi.org/10.12775/oec.2013.011.

\section{Akty prawne, dokumenty}

European Investment Bank, Statute and other Treaty provisions, Version dated 1 March 2020, 2020.

Ostateczne przyjęcie (UE, Euroatom) 2021/417 budżetu ogólnego Unii Europejskiej na rok budżetowy 2021 (Dz.Urz. UE L 93 z dnia 17 marca 2021 r.).

Regulation on Brexit Adjustment Reserve (BAR) - Analysis of the final compromise text with a view to agreement (COM(2020) 854 final) z dnia 25 czerwca 2021 r. 
Rozporządzenie Rady (EU, Euratom) 2020/2093 z dnia 17 grudnia 2020 r. określające wieloletnie ramy finansowe na lata 2021-2027 (Dz.Urz. UE L 433 I z dnia 22 grudnia 2020 r.).

Umowa o wystąpieniu Zjednoczonego Królestwa Wielkiej Brytanii i Irlandii Północnej z Unii Europejskiej i Europejskiej Wspólnoty Energii Atomowej (Dz.Urz. UE C 384 I z dnia 12 listopada 2019 r.).

Wniosek Rozporządzenie Parlamentu Europejskiego i Rady ustanawiające pobrexitową rezerwę dostosowawczą (COM(2020) 854 final) z dnia 25 grudnia 2020 r.

\section{Strony internetowe}

European Commission, Future Financing of the EU. Final Report and Recommendations of the High Level Group on Own Resource, 2016, https://ec.europa.eu/info/sites/default/files/about_the_european_commission/ eu_budget/future-financing-hlgor-final-report_2016_en.pdf.

European Commission, Speech by Michel Barnier at the Press Conference Following the Third Round of Article $50 \mathrm{Ne-}$ gotiations with the United Kingdom, 2017, http://europa.eu/rapid/press-release_SPEECH-17-3043_en.htm.

European Investment Bank, EIB President Regrets Brexit and Welcomes EU 27 United Support for EIB Group, http:// www.eif.europa.eu/what_we_do/news/eib-president-regrets-brexit-welcomes-eu27-united-support-for-eib-group.htm?lang=-en.

Komisja Europejska, Finansowanie planu odbudowy dla Europy, 2020, https://ec.europa.eu/info/sites/default/ files/about_the_european_commission/eu_budget/2020.2139_pl_04.1.pdf.

Komisja Europejska, Rabaty: mechanizmy korekty, https://ec.europa.eu/info/strategy/eu-budget/long-term-eu-budget/2021-2027/revenue/rebates_pl.

Komisja Europejska, Roczny budżet UE, https://ec.europa.eu/info/strategy/eu-budget/annual-eu-budget/all-annual-budgets_pl.

Komisja Europejska, Umowa o handlu i współpracy między UE a Wielka Brytaniq, https://ec.europa.eu/info/relations-united-kingdom/eu-uk-trade-and-cooperation-agreement_pl. 